Misr J. Ag. Eng., 26(4): 1933- 1951

PROCESS ENGINEERING

\title{
STUDY ON PHYSICAL AND ENGINEERING PROPERTIES FOR GRAINS OF SOME FIELD CROPS
}

\author{
El Fawal ,Y.A. ${ }^{*}$; M.A. Tawfik ${ }^{* *}$ and A.M. El Shal **
}

\section{ABSTRACT}

The present study aimed to determine and recognize a database of physical and engineering properties of grains of some main and popular feed, industrial crops which play an important role in designing and developing of specific machines and their operations such as planting, harvesting and grading. The studied crops namely fennel flower, rice (Giza101), rice (Giza 177), broad bean, corn (hyb. 310), corn (hyb. 352), wheat (Giza9) and wheat (Giza 168)and their selection based on their recent coverage area and the expected future expansion of each variety. Various physical properties including grain dimensions (length, width and thickness), the weight of thousand grain, bulk density, percent of sphericity, projected area, and the mechanical properties including angle of repose and coefficient of friction, in addition to the aerodynamic properties including terminal velocity, drag coefficient and Reynold's number, were determined at storage moisture content $7-12 \%(w b)$. The obtained data showed that it is recommended to use the stainless steel or galvanized iron in manufacturing of seed hopper used in planting machines, silos and storage containers with sides inclination of $40^{\circ}$ to allow an easily sliding for the studied grains.. The physical properties of seed play an important role to select the proper separating and cleaning equipment and the main dimensions are considered in selecting and designing the suitable size of the screen perforations. Also, the average terminal velocities of grains were 4.17, 7.32, 7.02, 20.16, 15.34, 14.69, 8.00 and $7.58 \mathrm{~m} / \mathrm{s}$ for fennel flower, rice (Giza101), rice (Giza 177), broad bean, corn (hyb. 310), corn (hyb. 352), wheat (Giza9) and wheat (Giza 168) respectively. Reynold's number of the terminal velocities of the studied grains exceeds the critical velocity of Reynold's number $\left(R_{N}=2100\right)$ in the range of turbulent flow except the fennel flower seeds.

\footnotetext{
* Researcher, Agric. Eng. Res. Inst., Giza, Egypt.

** Lecturer, Agric. Eng. Dept. Fac. of Agric., Zagazig Univ., Egypt.
} 


\section{INTRODUCTION}

$\mathrm{I}$ dentifying the physical and engineering characteristics of cereal crop grains is very important to optimize the design parameters of agricultural equipment used in their production ,handling and storage processes. So, it is essential to determine and recognize the database of physical and engineering (aerodynamic and mechanical) properties of these agricultural products because these properties play an important role in designing and developing of specific machines and their operations such as sorting, separating and cleaning, also to determine the optimum in seed metering device in pneumatic planter and precision sowing machine to suite every size of these grains. Hence, this study aimed to determine the optimum values of the basic physical and engineering properties of grains of some main and popular feed crops to utilize the obtained results to optimize the best design parameters in agricultural equipment. Klenin et. al. (1985) mentioned that, the behavior of particles in air stream is diameter of holes in seed metering devices in planting, air suction suitable for seed holding governed by their aerodynamic properties of particles , the critical velocity (terminal velocity) $V_{c r}$, resistance coefficient of the air $\left(K_{r}\right)$ and drift coefficient $\left(K_{d}\right)$. Sitkei (1987) reported that the functioning of many types of agricultural machines (sifters, sowing machines, pneumatic transport systems, etc.) is influenced by the physical properties of the objects participating, and so in order to study a given process they must be described accurately, Also the quality of processing (in chopping and milling) may be characterized by a products mean size and mean standard deviation, or these data may be used to organize a technological process or in designing certain structural elements (mesh dimensions of sifters or dimensions of screen holes).He added that during the treatment of agricultural materials air is often used the transport medium, pneumatic transport and cleaning of various agricultural products have been known for along time, during this process aerodynamic properties play an important role and must be known for optimum design and the operation of the equipment. The two most important aerodynamic properties of a body are drag coefficient and terminal velocity. Sabbah et al. (1994) studied the effect of moisture content on the physical properties for three Egyptian paddy rice varieties. 
They recorded the increase occurring in seed sphericity (S) due to the increase of moisture content . EL-Sahrigi (1997) indicated that it is essential to understand the physical and engineering law governing the response of agricultural biological material, so that processing and handling machines can be designed for maximum efficiency and highest quality of the end product .Kochhar and Hira (1997) reported that to design equipment and facilities for handling processing and storage, the physical properties of crop grains must be known. Lgathinathane and Hana(1998) reported that some seeds, fruits and vegetables of spherical in shape with variation along one or both axes. In general, to specify the shape of a food material it is necessary to identify three basic dimensions, namely, length, width and thickness. A body can be defined by one or two significant dimensions only in a few special cases where the body approximates to a regular geometrical shape such as a sphere, cylinder, prolate spheroid or oblate spheroid. Nimkar and Chattopadhyay (2001) reported that various physical properties of green gram were evaluated as a function of moisture content in the range of 8.39 to $33.40 \%$ d.b.. The average length, width, thickness and the mass of thousand seeds were $4.21 \mathrm{~mm}, 3.17 \mathrm{~mm}, 3.08 \mathrm{~mm}$, and $28.19 \mathrm{~g}$ respectively at moisture content of $8.39 \%$ (d.b.), Also, the average geometric diameter increased from $3.45 \mathrm{~mm}$ to $3.77 \mathrm{~mm}$, whereas sphericity decreased from 0.840 to 0.815 . They added that by increasing moisture content the bulk and true densities decreased from 807 to $708 \mathrm{~kg} / \mathrm{m}^{3}$ and 1363 to $1292 \mathrm{~kg} / \mathrm{m}^{3}$, respectively, whereas the corresponding bulk porosity increased from 40.77 to $45.16 \%$. Nonami and Nelson (2002) conducted a study to enable easy seed and waste separation at head feed combine by measuring the terminal velocity. It was found that, it is difficult to separate seeds with primary branches and straws from a single seed in the tank because the terminal velocity of the seed with primary branches and straw was more than the single seed. The suitable limits of the separating air velocity was from 2.3 to $6.5 \mathrm{~m} / \mathrm{s}$.. Matouk et al. (2004) developed the mathematical relationships relating the changes of the properties with the seed moisture content. The seed principal dimensions, mass of 1000 seeds and seed projection area are generally increased by increasing of seed moisture content. However, both shape-index and coefficient of contact 
surface are decreased by increasing of seed moisture content. The main objectives of this study are to (1)determine the basic physical and engineering properties of some main and popular feed crops (2).investigate the relationship between these grains properties affecting the agricultural mechanization.

\section{MATERIALS AND METHODS}

To achieve the target of this experimental work, some varieties of main crops namely (wheat, rice, corn, broad bean, and fennel flower) which represent the major important food; industrial crops in Egypt, were selected based on their recent coverage area and the expected future expansion of each variety. Samples of the selected varieties of each crop were procured from the experimental farm of Gemmiza Agricultural Research Station, El-Gharbia Governorate, Egypt and cleaned from foreign matters, broken and immature grains. Random samples of $5 \mathrm{~kg}$ from raw grain lots were taken and used 150 of grains for varieties from each crop at storage moisture content $(7-12 \%)$ to determine the optimum physical and engineering (aerodynamic and mechanical) properties.

\section{$\underline{\text { A-Materials }}$}

The study was carried out using local varieties of some main field crops namely: wheat (Giza 9 and Giza 168), corn (hybrid 310 and hybrid 352), rice (Giza 101 and Giza 177), In addition to broad bean and fennel flower as a medical crop.

\section{B-Instrumentation}

\section{Electronic digital balance}

The electronic balance was made in Japan and used in this study for measuring the mass of samples. It was used in determining particles mass with an accuracy of $0.1 \mathrm{mg}$.

\section{Electronic digital vernier calipar}

It was used for measuring the dimensions of grains and their associated foreign matters. It was made in Japan, model METR ISO_G.The range of reading is 0.01 to $15 \mathrm{~mm}$ with an accuracy of $0.05 \mathrm{~mm}$.

\section{Digital-hydrometer-moisture content-meter}

Model G-86, with an accuracy of $0.1 \%$. It was made in Germany and used for measuring the moisture content in percentage of the studied seeds on wet basis. 


\section{Anemometer}

It was Tri-sense. Hygrometer/Anemometer/ Thermometer. Model No. 37000-00. Cole Parmer Instrument Company, Illinois, USA. It was used for measuring air velocity by $\mathrm{m} / \mathrm{s}$.

\section{Terminal velocity apparatus}

The apparatus used in this study was constructed in the workshop of Agric. Eng. Res. Inst., in Gemmiza Agricultural Research Station, ElGharbia Governorate, Egypt. The apparatus as shown in Fig .(1), consists of an electric blower which discharge air blast into a transparent tapered tube used as a cyclone which is fixed at the outlet side of the blower through an elbow. A screen is fitted at the bottom of the transparent tapered tube of $8 \times 4 \mathrm{~cm}$ cross section and a cyclone is fitted at the top of it $15 \mathrm{~cm}$ square cross section. A chock valve is built at the bottom of the cyclone to control the air flow rate. The chock valve is manually adjusted by the control lever.

\section{Angle of repose meter}

It was used for measuring the angle between the base and the slope of the cone formed due to a free vertical fall of the seed mass.

\section{Digital instrument for measuring the friction angle}

It was used for measuring the friction angle and the repose angle for the studied seeds on metal-sheet surface with dimensions $14 \times 31.5 \mathrm{~cm}$. The digital measuring device designed and constructed in Meet-EL-Dieba at Kafr El-shieakh Governorate, Egypt at the laboratory of Rice Mechanization Center (RMC).

\section{Graduated cylinder}

It was used for measuring volume for the investigated crops seeds to obtain real and bulk density.

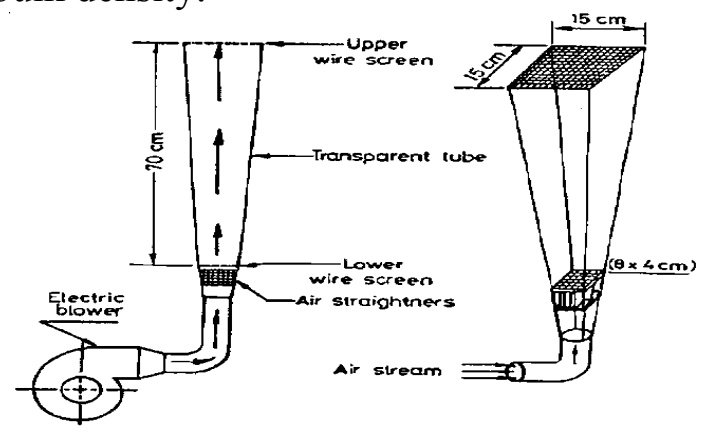

Fig.(1): Terminal velocity apparatus 


\section{Experimental procedures:}

The main experiments were conducted to determine and calculate the physical, aerodynamic and mechanical properties of crops varieties under study. Grain dimensions (length, width and thickness), mass of thousand grain , volume, geometric diameter, arithmetic diameter, bulk and real densities, percent of sphericity, projected area, terminal velocity, drag coefficient, Reynold's number, angle of repose and coefficient of friction were measured and estimated. All the experiments were replicated five times, stated and the average values were recorded.

\section{a- Physical properties of crop seeds varieties}

Grain dimensions (L,W and T), mass of thousand grain, volume, geometric diameter, arithmetic diameter, bulk and real densities, percent of sphericity and projected area. Standard Deviation, coefficient of variation, maximum, minimum and arithmetic mean for grains varieties under studies. The calculated equations according to EL-Raie et al. (1996) studied that, the size of the three varieties of corn in terms of length (L), width (W) and thickness (T). The size was used to calculate the volume $(\mathrm{V})$, geometric diameter $(\mathrm{D} g)$, arithmetic diameter $(\mathrm{D} a)$, percent of sphericity $(\mathrm{S})$, area of surface $(\mathrm{A} f)$, and area of transverse surface (At) of the individual seeds. The following equations were used to calculate the values of the above mentioned properties:

$$
\begin{array}{ll}
V=\frac{\pi}{6} L W T & , \mathrm{~mm}^{3} \\
D_{g}=(L W T)^{1 / 3} & , \mathrm{~mm} \\
D_{a}=\frac{(L+W+T)}{3} & , \mathrm{~mm} \\
S=\frac{(L W T)^{1 / 3}}{L} \times 100 & , \% \\
A_{f}=\frac{\pi}{4} L W & , \mathrm{~mm}^{2} \\
A_{t}=\frac{\pi}{4} T W & , \mathrm{~mm}^{2}
\end{array}
$$

Where:

$\mathrm{L}$ :length of seed ,mm $\quad, \quad \mathrm{W}$ : width of seed ,mm

$\mathrm{T}$ : thickness of seed ,mm 


$$
\rho_{b}=\frac{m}{v}
$$

Where:

$$
\begin{aligned}
& \rho_{b} \text { : bulk density of the grain, } \mathrm{g} / \mathrm{cm}^{3}, \quad m: \text { mass of grains , } \mathrm{g} \\
& v: \text { bulk volume of the grains }, \mathrm{g} / \mathrm{cm}^{3}
\end{aligned}
$$

\section{b- Aerodynamic properties of crop seeds varieties}

The terminal velocity of crop seeds is determined by measuring the air velocities, required to suspend a seed in a vertical air stream by using terminal velocity apparatus. Drag coefficient and Reynold's number were calculated according to equations of Hexing (1989) as follows:

$$
C_{d}=\frac{2 g F_{d}}{A_{p} \rho_{a} v_{t}^{2}} \quad, \quad N_{\mathrm{Re}}=\frac{\rho_{a} v_{t} \sqrt{A_{p}}}{\mu}
$$

Where:

$V_{t}:$ terminal velocity, $\mathrm{m} / \mathrm{s}$ $g$ : gravity, $\mathrm{m} / \mathrm{s}^{2}$

$A_{p}:$ projected area of particle, $\mathrm{m}^{2}$ $F_{d}:$ drag force , $\mathrm{N}$

$\mu$ :dynamic viscosity of the air, $\left(18.10^{-6}\right)$ $C_{d}$ : drag coefficient $\rho_{a}:$ density of air, $\left(1.28 \mathrm{~kg} / \mathrm{m}^{3}\right)$

\section{C-Mechanical properties of crop seeds varieties}

\section{-Angle of repose}

Seeds were poured under gravity from a suitable height to form a cone surface and the horizontal plan was recorded to represent repose angle of seeds using the repose angle meter.

\section{-Friction coefficient}

The seeds sample was placed over the surface to be tested, which is titled around its side pivot. The friction angle was displayed when $75 \%$ of the seeds reached the spout and the tray was stopped.Friction coefficient for the mentioned sample was obtained as follows:

$$
\text { Friction coefficient }=\tan \alpha
$$

Where: $\alpha=$ Friction angle. 


\section{RESULTS AND DISCUSSION}

A random sample of about 150 seeds was taken from each crop to obtain data about some physical properties such as ,length ,width, thickness ,mass of thousand seeds, volume of seed, arithmetic diameter, geometric diameter, flat surface area, transverse area and sphericity. The measured moisture content ranged from 7 to $12 \%$ (w.b.). The mechanical properties such as; angle of repose and coefficient of friction of some field crop grains with different types of materials are displayed in Table.(1) also, the bulk density of grains as shown in Table (3).

Table(1): Average values of dynamic angle of repose and coefficient of friction of some field crop grains with different materials

\begin{tabular}{|l|c|c|c|c|c|}
\hline \multirow{2}{*}{\multicolumn{1}{|c|}{ Crop }} & \multicolumn{5}{c|}{ Dynamic angle of repose, degrees } \\
\cline { 2 - 6 } & Glass & Plywood & Galv. iron & Wood & Stain. steel \\
\hline Fennel flower & 11.85 & 18.26 & 20.80 & 26.56 & 13.50 \\
\hline Rice (Giza 101) & 20.80 & 24.70 & 22.78 & 29.24 & 15.64 \\
\hline Rice (Giza 177) & 21.30 & 26.56 & 24.70 & 30.11 & 12.40 \\
\hline Broad bean & 19.80 & 17.22 & 21.80 & 23.74 & 19.29 \\
\hline Corn( hyb. 310) & 21.80 & 20.80 & 22.78 & 30.96 & 23.75 \\
\hline Corn (hyb. 352) & 20.80 & 19.80 & 22.30 & 29.24 & 22.30 \\
\hline Wheat (Giza9) & 14.57 & 16.70 & 26.42 & 25.17 & 16.70 \\
\hline Wheat (Giza168) & 15.64 & 18.79 & 22.30 & 26.10 & 18.26 \\
\hline \multirow{2}{*}{ Crop } & \multicolumn{5}{|c|}{ Coefficient of friction } \\
\cline { 2 - 7 } & Glass & Plywood & Galv. iron & Wood & Stain. steel \\
\hline Fennel flower & 0.21 & 0.33 & 0.38 & 0.50 & 0.24 \\
\hline Rice Giza(101) & 0.38 & 0.46 & 0.42 & 0.56 & 0.28 \\
\hline Rice Giza (177) & 0.39 & 0.50 & 0.46 & 0.58 & 0.22 \\
\hline Broad bean & 0.36 & 0.31 & 0.40 & 0.44 & 0.35 \\
\hline Corn (hyb. 310) & 0.40 & 0.38 & 0.42 & 0.60 & 0.44 \\
\hline Corn(hyb. 352) & 0.38 & 0.36 & 0.41 & 0.56 & 0.41 \\
\hline Wheat (Giza9) & 0.26 & 0.30 & 0.37 & 0.47 & 0.30 \\
\hline Wheat (Giza168) & 0.28 & 0.34 & 0.41 & 0.49 & 0.33 \\
\hline
\end{tabular}

Table (2): Average values of static angle of repose of some field crop grains .

\begin{tabular}{|c|c|c|c|c|c|c|c|c|}
\hline Crop & $\begin{array}{c}\text { fennel } \\
\text { flower }\end{array}$ & $\begin{array}{c}\text { rice } \\
\text { Giza } \\
101\end{array}$ & $\begin{array}{c}\text { rice } \\
\text { Giza } \\
177\end{array}$ & $\begin{array}{c}\text { broad } \\
\text { bean }\end{array}$ & $\begin{array}{c}\text { corn } \\
\text { hyb310 }\end{array}$ & $\begin{array}{c}\text { corn } \\
\text { hyb352 }\end{array}$ & $\begin{array}{c}\text { wheat } \\
\text { Giza9 }\end{array}$ & $\begin{array}{c}\text { wheat } \\
\text { Giza } \\
168\end{array}$ \\
\hline $\begin{array}{c}\text { Static angle } \\
\text { of repose } \\
\text { (degree) }\end{array}$ & 32.20 & 36.60 & 37.80 & 15.40 & 21.70 & 22.60 & 27.40 & 28.50 \\
\hline
\end{tabular}


Table (3): Bulk density of some field crop grains

\begin{tabular}{|c|c|c|c|c|c|c|c|c|}
\hline Crop & $\begin{array}{c}\text { fennel } \\
\text { flower }\end{array}$ & $\begin{array}{c}\text { rice } \\
\text { Giza } \\
101\end{array}$ & $\begin{array}{c}\text { rice } \\
\text { Giza } \\
177\end{array}$ & $\begin{array}{c}\text { broad } \\
\text { bean }\end{array}$ & $\begin{array}{c}\text { corn } \\
\text { hyb310 }\end{array}$ & $\begin{array}{c}\text { corn } \\
\text { hyb352 }\end{array}$ & $\begin{array}{c}\text { wheat } \\
\text { Giza9 }\end{array}$ & $\begin{array}{c}\text { wheat } \\
\text { Giza } \\
168\end{array}$ \\
\hline $\begin{array}{c}\text { Bulk density } \\
\left(\mathrm{kg} / \mathrm{m}^{3}\right)\end{array}$ & 550 & 600 & 630 & 410 & 800 & 830 & 742 & 800 \\
\hline
\end{tabular}

\section{Grain mechanical properties}

\section{-Static angle of repose:}

The represented data in Table (2) show that the values of static angle of repose were determined as 32.20, 36.60, 37.80, 15.40, 21.70, 22.60, 27.40 and 28.50 degree for fennel flower, rice (Giza101), rice (Giza 177), broad bean, corn (hyb.310), corn (hyb.352), wheat (Giza9) and wheat (Giza 168) respectively. It is clear that angle of repose of grain was decreased as the size of grain increased especially when the surface of grain becomes more smooth at storage moisture content. The previous data can be utilized to assess the optimum sides inclination of seed hopper in planting machines, silos and storage containers to allow an easily sliding.

\section{-Coefficient of friction:}

Coefficient of friction is the tangent of dynamic angle of repose. It is estimated with different types of surfaces including, glass, plywood, galvanized iron, wood and stainless steel. The obtained results in Table (1) indicate that the maximum values of coefficient of friction were obtained on the surface of wood and the minimum were obtained on the glass also, the surface of the stainless steel gives the second lowest values of coefficient of friction and it is recommended to use this material in the structure of seed hopper in planters, silos and storage containers.

\section{Grain physical properties}

\section{-Thousand seed weight:}

The average mass values of thousand seed was determined as 2.64, $26.79,25.54,862.46,422.86,302.60,46.98$, and $42.16 \mathrm{gm}$ for fennel flower, rice (Giza101), rice (Giza 177), broad bean, corn (hyb.310), corn (hyb.352), wheat (Giza9) and wheat (Giza 168) respectively. Estimating the mass of seed is necessary to assess the required mass of seed for planting a limited area and number of seed in each hole. 


\section{-Bulk density:}

The bulk density was determined as 550, 600, 630, 410,800, 830, 742 and $800 \mathrm{~kg} / \mathrm{m}^{3}$ for fennel flower, rice (Giza101), rice (Giza 177), broad bean, corn (hyb.310),corn (hyb.352), wheat (Giza9) and wheat (Giza 168) respectively at storage moisture content. The bulk density is considered for determination of paging capacity, designing seed hopper dimensions in seed planters and cleaning and grading equipment.

\section{-Grain size and shape:}

The obtained data in Tables (4) to (11) show that the geometric diameter, arithmetic diameter and sphericity were determined for the studied grains and Figs. (2) to (9) display the variation of the seed three axial dimensions, length (L), width (W) and thickness (T) for fennel flower seeds, it is observed from Fig.(2) that the highest frequency distribution for(L) was $85.05 \%$ ranging from 2.5 to $3 \mathrm{~mm}$ and for(W) was $100 \%$ ranging from 1 to $1.5 \mathrm{~mm}$ and for $(\mathrm{T})$ was $74.77 \%$ ranging from 0.50 to $1.00 \mathrm{~mm}$, and with mean of $2.89,1.25$ and $0.904 \mathrm{~mm}$ for (L), (W) and (T) respectively. Figs.(3) and (4) illustrate that, for the studied varieties of rice crop( Giza 101 and Giza 177), the highest frequency distribution of (L),(W) and (T) for both varieties were ( 60-60.67\%), (54-34.67\%) and $(60-54 \%)$ respectively. The range of grains width (W) were(3 to $3.5 \mathrm{~mm}$ ) and (3.5 to $4 \mathrm{~mm}$ ) for Giza 101 and Giza 177 respectively but both varieties have the same range of $(\mathrm{L})(7 \mathrm{to} 7.5 \mathrm{~mm})$ and $(\mathrm{T})$ (2 to 2.5 $\mathrm{mm})$. The mean for both varieties were $(7.33-7.32 \mathrm{~mm}),(3.52-3.81 \mathrm{~mm})$ and $(2.46-2.57 \mathrm{~mm})$ for $(\mathrm{L}),(\mathrm{W})$ and $(\mathrm{T})$ respectively. For broad bean, Fig.(5) show that the highest frequency distribution of (L) was $28 \%$ ranging from 16 to $16.50 \mathrm{~mm}$, for (W) was $38 \%$ ranging from 13.5 to $14 \mathrm{~mm}$ and for (T) was $22 \%$ ranging from 9 to $9.5 \mathrm{~mm}$ with mean of 16.25, 13.75and $8.53 \mathrm{~mm}$ for(L), (W) and (T) respectively. Figs.(6) and (7) show that, for the studied varieties of corn $\operatorname{crop}($ hyb.310 and hyb.352) the highest frequency distribution of $(\mathrm{T})$ for both varieties were (24-36\%) respectively, and the same frequency of (L) (16.67\%) and (W) $(18 \%)$ were observed for both varieties .The range of grains length were $(11$ to $11.5 \mathrm{~mm})$ and $(12$ to $12.5 \mathrm{~mm})$ for hyb.310 and hyb.352 respectively but width was ( 9 to9.5mm) for both varieties and the same range of thickness (4 to $4.50 \mathrm{~mm}$ )was observed. The mean for both 
varieties were (11.74- 12.3mm), (9.13-8.24mm) and (4.37 -4.53mm) for $(\mathrm{L}),(\mathrm{W})$ and $(\mathrm{T})$ respectively. It is clear that no significant differences in the three axial dimensions for both varieties. Figs.(8) and (9) illustrate that, for the studied varieties of wheat crop (Giza 9 and Giza 168) the highest frequency distribution of $(\mathrm{L}),(\mathrm{W})$ and $(\mathrm{T})$ for both varieties were (64.67-64\%), (36-44.67\%) and (45.33-37.33\%) respectively and the both varieties have the same range (6 to $6.5 \mathrm{~mm}$ ) and (3 to $3.5 \mathrm{~mm}$ ) for (L), and $(\mathrm{T})$ respectively, while the range of $(\mathrm{W})$ were $(4 \mathrm{to} 4.5 \mathrm{~mm})$ and $(3$ to $3.5 \mathrm{~mm}$ ) for Giza9 and Giza168 respectively. The mean for both varieties were $(6.35-6.25 \mathrm{~mm}),(3.94-3.62 \mathrm{~mm})$ and $(3.21-3.20 \mathrm{~mm})$ for $(\mathrm{L})$ , (W) and (T) respectively. Main dimensions of grain are considered in selecting, designing the suitable size of the screen perforations and determination the proper method for grading and separation.

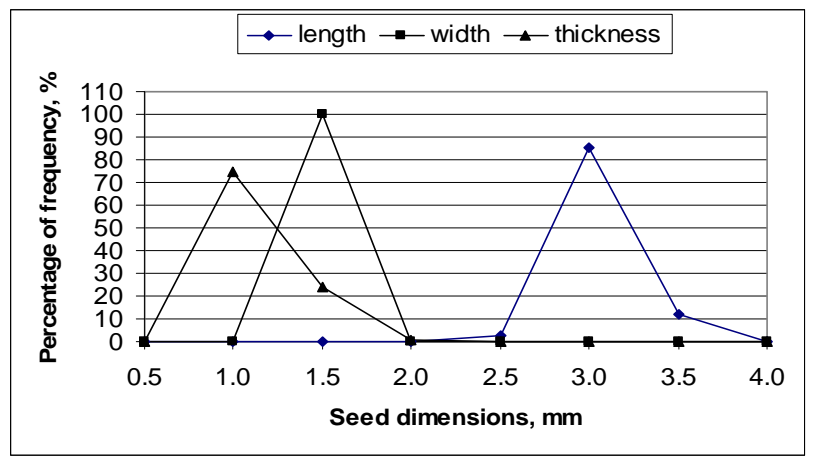

Fig.(2): Frequency distribution curves for fennel flower seed dimensions.

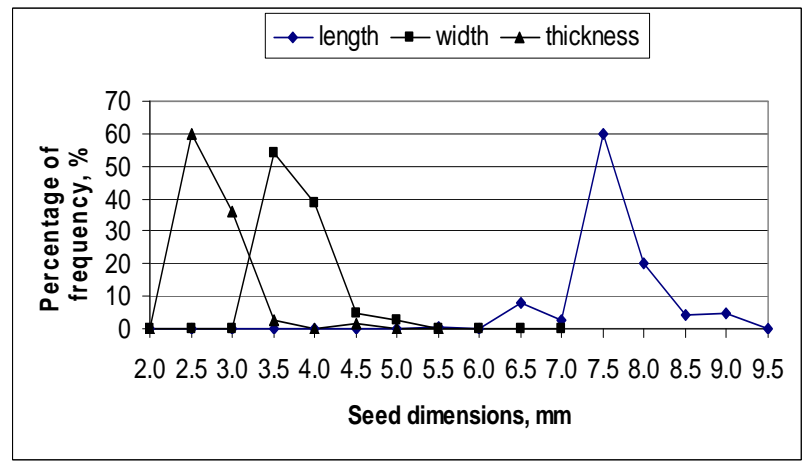

Fig. (3): Frequency distribution curves of rice (Giza101) seeds dimensions. 


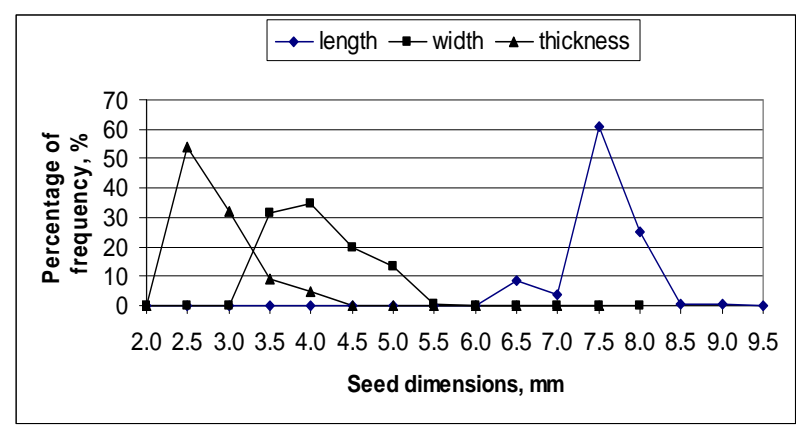

Fig. (4): Frequency distribution curves of rice (Giza177) seeds dimensions.

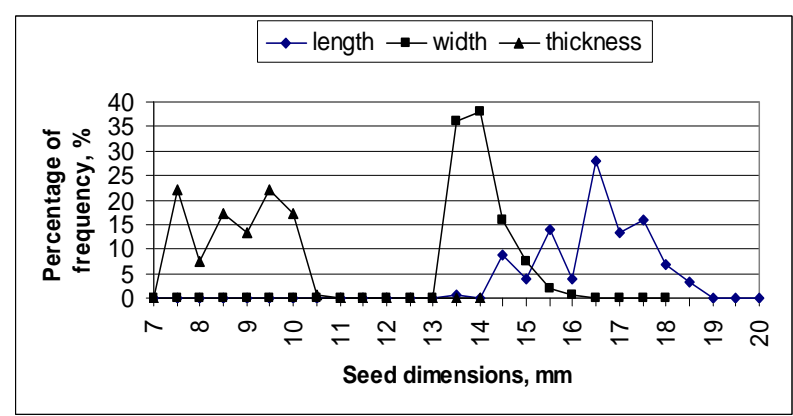

Fig. (5): Frequency distribution curves of broad bean seeds dimension

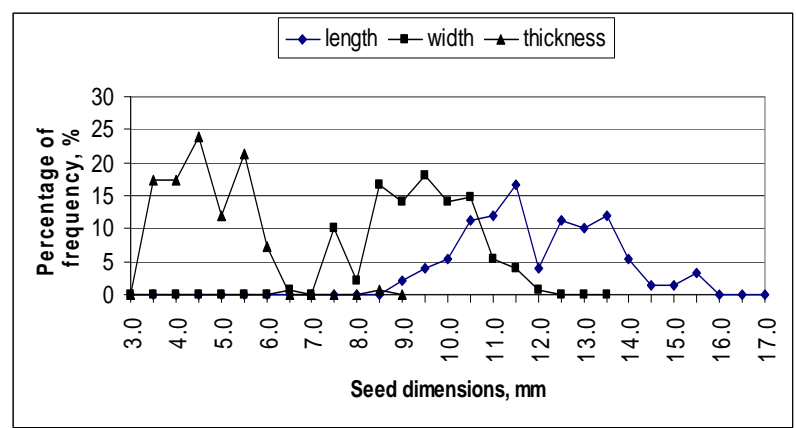

Fig. (6): Frequency distribution curves of corn (hyb. 310) seeds dimensions.

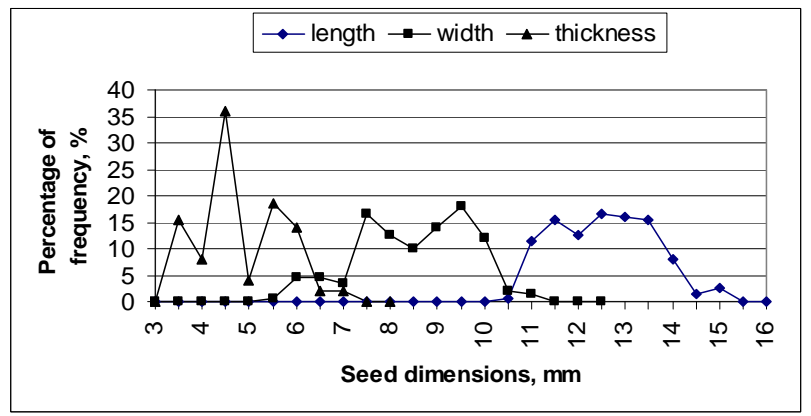

Fig. (7): Frequency distribution curves of corn (hyb. 352) seeds dimensions. 


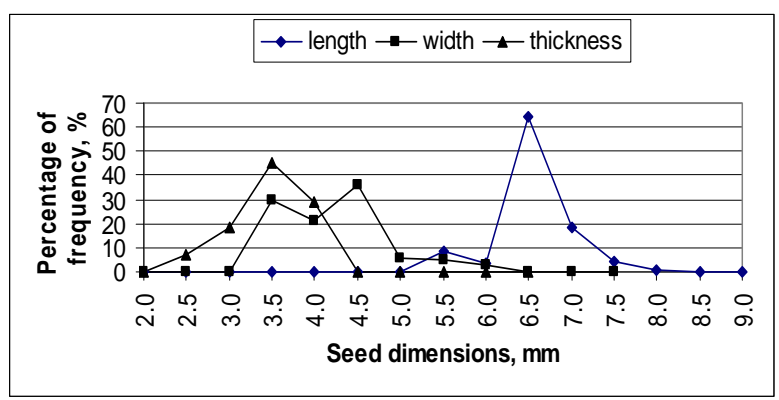

Fig. (8): Frequency distribution curves of wheat (Giza 9) seeds dimensions.

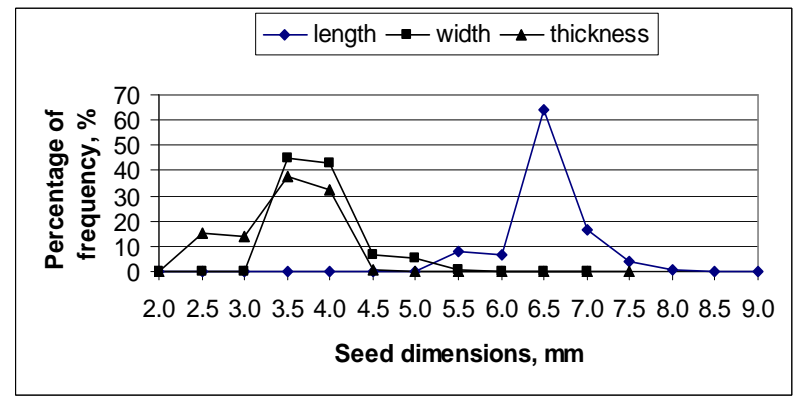

Fig. (9): Frequency distribution curves of wheat (Giza 168) seed dimensions.

\section{Grain aerodynamic properties}

\section{-Terminal velocity:}

The represented data in Tables (4) to (11) reveal that, the average terminal velocities for the studied grains were determined as 4.17, 7.32, 7.02, 20.16, 15.34, 14.69, 8.00 and $7.58 \mathrm{~m} / \mathrm{s}$ for fennel flower, rice (Giza101), rice (Giza 177), broad bean, corn (hyb. 310), corn (hyb. 352), wheat (Giza9) and wheat (Giza 168) respectively. The previous results showed a variation in terminal velocity for the varieties of the same crop due to the variation in particle mass, air and particle density. Hence, the difference in terminal velocity offers the possibility of separating such materials from each other in an air stream and it can be utilized in designing air screen, threshing, cleaning and grading equipment

\section{-Reynold's number:}

Projected area, drag coefficient and Reynold's number were determined. The obtained results indicated that Reynold's number of the terminal velocity of the studied grains exceeds the critical velocity of (2100) ELRaie et al. (1996), in the range of turbulent flow except the fennel flower seeds. So, it is necessary to determine the Reynold's number for the different varieties of each crop. 
Table (4): Some physical and aerodynamic properties of fennel flower seed.

\begin{tabular}{|c|c|c|c|c|c|c|c|}
\hline symbol & $\mathrm{L}$ & $\mathrm{W}$ & $\mathrm{T}$ & $\mathrm{V}$ & $D_{g}$ & $D_{a}$ & $A_{p}$ \\
\hline Max. & 3.160 & 1.410 & 1.900 & 3.704 & 1.920 & 2.043 & 3.398 \\
\hline Min. & 2.390 & 1.010 & 0.600 & 1.117 & 1.287 & 1.523 & 2.045 \\
\hline Sum. & 309.95 & 134.510 & 96.730 & 184.31 & 158.54 & 180.397 & 305.996 \\
\hline Mean & 2.897 & 1.257 & 0.904 & 1.723 & 1.482 & 1.686 & 2.860 \\
\hline St.Dev. & 0.132 & 0.070 & 0.165 & 0.341 & 0.093 & 0.074 & 0.220 \\
\hline C.V. & 4.572 & 5.581 & 18.298 & 19.781 & 6.268 & 4.401 & 7.698 \\
\hline symbol & $\mathrm{M}$ & $\mathrm{S} \%$ & $A_{f}$ & $A_{t}$ & $v_{t}$ & $C_{d}$ & $N_{\mathrm{Re}}$ \\
\hline Max. & 0.004 & 64.428 & 3.400 & 1.865 & 4.500 & 1.147 & 570.342 \\
\hline Min. & 0.002 & 42.122 & 2.046 & 0.564 & 3.500 & 0.632 & 378.620 \\
\hline Sum. & 0.283 & 5481.406 & 306.151 & 95.497 & 446.90 & 86.658 & 53683.883 \\
\hline Mean & 0.003 & 51.228 & 2.861 & 0.892 & 4.177 & 0.810 & 501.719 \\
\hline Std.Dev & 0.000 & 3.549 & 0.220 & 0.170 & 0.249 & 0.099 & 33.514 \\
\hline C.V. & 17.901 & 6.927 & 7.698 & 19.070 & 5.962 & 12.258 & 6.680 \\
\hline
\end{tabular}

Table (5): Some physical and aerodynamic properties of rice (Giza101).

\begin{tabular}{|c|c|c|c|c|c|c|c|}
\hline symbol & $\mathrm{L}$ & $\mathrm{W}$ & $\mathrm{T}$ & $\mathrm{V}$ & $D_{g}$ & $D_{a}$ & $A_{p}$ \\
\hline Max. & 8.980 & 4.900 & 4.130 & 58.605 & 4.820 & 5.163 & 29.011 \\
\hline Min. & 5.290 & 3.010 & 2.010 & 23.423 & 3.550 & 3.887 & 14.555 \\
\hline Sum. & 1099.50 & 527.850 & 369.950 & 4992.725 & 596.384 & 665.767 & 3036.930 \\
\hline Mean & 7.330 & 3.519 & 2.466 & 33.285 & 3.976 & 4.438 & 20.246 \\
\hline Std.Dev & 0.539 & 0.389 & 0.359 & 6.607 & 0.250 & 0.246 & 2.661 \\
\hline C.V. & 7.357 & 11.053 & 14.544 & 19.850 & 6.276 & 5.537 & 13.144 \\
\hline symbol & $\mathrm{M}$ & $\mathrm{S} \%$ & $A_{f}$ & $A_{t}$ & $v_{t}$ & $C_{d}$ & $N_{\mathrm{Re}}$ \\
\hline Max. & 0.035 & 72.469 & 29.026 & 12.098 & 9.000 & 0.662 & 3305.800 \\
\hline Min. & 0.003 & 45.326 & 14.563 & 5.099 & 5.700 & 0.062 & 1654.915 \\
\hline Sum. & 4.019 & 8169.295 & 3038.47 & 1023.5 & 1099.200 & 58.466 & 351118.8 \\
\hline Mean & 0.027 & 54.462 & 20.256 & 6.823 & 7.328 & 0.390 & 2340.792 \\
\hline Std.Dev & 0.003 & 4.507 & 2.662 & 1.315 & 0.848 & 0.080 & 316.078 \\
\hline C.V. & 12.815 & 8.276 & 13.144 & 19.278 & 11.578 & 20.633 & 13.503 \\
\hline
\end{tabular}

Table (6): Some physical and aerodynamic properties of rice (Giza177).

\begin{tabular}{|c|c|c|c|c|c|c|c|}
\hline symbol & $\mathrm{L}$ & $\mathrm{W}$ & $\mathrm{T}$ & $\mathrm{V}$ & $D_{g}$ & $D_{a}$ & $A_{p}$ \\
\hline Max. & 8.590 & 5.390 & 3.960 & 64.763 & 4.983 & 5.257 & 32.072 \\
\hline Min. & 6.280 & 3.010 & 2.020 & 24.440 & 3.601 & 3.980 & 15.734 \\
\hline Sum. & 1099.150 & 571.570 & 385.450 & 5644.114 & 620.269 & 685.390 & 3287.666 \\
\hline Mean & 7.328 & 3.810 & 2.570 & 37.627 & 4.135 & 4.569 & 21.918 \\
\hline Std.Dev & 0.364 & 0.522 & 0.426 & 8.785 & 0.308 & 0.263 & 3.183 \\
\hline C.V. & 4.963 & 13.695 & 16.561 & 23.348 & 7.455 & 5.755 & 14.525 \\
\hline symbol & $\mathrm{M}$ & $\mathrm{S} \%$ & $A_{f}$ & $A_{t}$ & $v_{t}$ & $C_{d}$ & $N_{\mathrm{Re}}$ \\
\hline Max. & 0.037 & 72.142 & 32.088 & 13.032 & 8.900 & 0.654 & 3198.765 \\
\hline Min. & 0.002 & 49.283 & 15.742 & 5.252 & 4.300 & 0.081 & 1327.054 \\
\hline Sum. & 3.832 & 8480.139 & 3289.33 & 1156.20 & 1053.600 & 56.177 & 349766.22 \\
\hline Mean & 0.026 & 56.534 & 21.929 & 7.708 & 7.024 & 0.375 & 2331.775 \\
\hline Std.Dev & 0.004 & 4.630 & 3.185 & 1.762 & 0.916 & 0.089 & 341.967 \\
\hline C.V. & 15.686 & 8.189 & 14.525 & 22.863 & 13.037 & 23.692 & 14.666 \\
\hline
\end{tabular}


Table (7) :Some physical and aerodynamic properties of broad bean.

\begin{tabular}{|c|c|c|c|c|c|c|c|}
\hline symbol & $\mathrm{L}$ & $\mathrm{W}$ & $\mathrm{T}$ & $\mathrm{V}$ & $D_{g}$ & $D_{a}$ & $A_{p}$ \\
\hline Max. & 18.410 & 15.980 & 10.170 & 1397.336 & 13.873 & 14.337 & 214.315 \\
\hline Min. & 13.330 & 13.010 & 7.010 & 720.118 & 11.123 & 11.547 & 136.974 \\
\hline Sum. & 2437 & 2062.880 & 1280.380 & 149673.55 & 1856.453 & 1926.897 & 26313.987 \\
\hline Mean & 16.250 & 13.753 & 8.536 & 997.824 & 12.376 & 12.846 & 175.427 \\
\hline Std.Dev & 1.072 & 0.549 & 0.935 & 131.666 & 0.544 & 0.494 & 13.546 \\
\hline C.V. & 6.597 & 3.992 & 10.950 & 13.195 & 4.397 & 3.844 & 7.722 \\
\hline symbol & $\mathrm{M}$ & $\mathrm{S} \%$ & $A_{f}$ & $A_{t}$ & $V_{t}$ & $C_{d}$ & $N_{\text {Re }}$ \\
\hline Max. & 1.280 & 88.762 & 214.424 & 114.219 & 26.550 & 0.325 & 25467.554 \\
\hline Min. & 0.540 & 66.723 & 137.044 & 72.730 & 12.850 & 0.134 & 11352.167 \\
\hline Sum. & 129.37 & 11460.38 & 26327.33 & 13828.88 & 3023.940 & 28.574 & 2845225.457 \\
\hline Mean & 0.862 & 76.403 & 175.516 & 92.193 & 20.160 & 0.190 & 18968.170 \\
\hline Std.Dev & 0.145 & 4.706 & 13.553 & 10.632 & 3.098 & 0.033 & 2983.259 \\
\hline C.V. & 16.787 & 6.160 & 7.722 & 11.532 & 15.370 & 17.135 & 15.728 \\
\hline
\end{tabular}

Table (8): Some physical and aerodynamic properties of corn (hyb.310).

\begin{tabular}{|c|c|c|c|c|c|c|c|}
\hline symbol & $\mathrm{L}$ & $\mathrm{W}$ & $\mathrm{T}$ & $\mathrm{V}$ & $D_{g}$ & $D_{a}$ & $A_{p}$ \\
\hline Max. & 15.390 & 11.570 & 8.180 & 442.452 & 9.456 & 10.383 & 130.043 \\
\hline Min. & 8.690 & 6.010 & 3.010 & 101.683 & 5.792 & 6.357 & 49.361 \\
\hline Sum. & 1761.880 & 1369.850 & 655.930 & $\mathbf{3 6 8 0 1 . 5 5 5}$ & 1156.786 & 1262.553 & 12712.877 \\
\hline Mean & 11.746 & 9.132 & 4.373 & 245.344 & 7.712 & 8.417 & 84.753 \\
\hline Std.Dev & 1.494 & 1.108 & 0.848 & 61.773 & 0.668 & 0.738 & 17.619 \\
\hline C.V. & 12.718 & 12.132 & 19.389 & 25.178 & 8.658 & 8.772 & 20.789 \\
\hline Symbol & $\mathrm{M}$ & $\mathrm{S} \%$ & $A_{f}$ & $A_{t}$ & $\boldsymbol{V}_{t}$ & $C_{d}$ & $N_{\mathrm{Re}}$ \\
\hline Max. & 0.590 & 88.372 & 130.109 & 48.355 & 16.970 & 0.573 & 13687.853 \\
\hline Min. & 0.210 & 51.756 & 49.386 & 17.012 & 14.210 & 0.180 & 7261.607 \\
\hline Sum. & 63.430 & 9946.311 & 12719.325 & 4694.66 & 2301.650 & 50.323 & 1499548.836 \\
\hline Mean & 0.423 & 66.309 & 84.796 & 31.298 & 15.344 & 0.335 & 9996.992 \\
\hline Std. Dev & 0.079 & 7.138 & 17.628 & 6.689 & 0.710 & 0.078 & 1206.270 \\
\hline C.V. & 18.639 & 10.764 & 20.789 & 21.373 & 4.630 & 23.167 & 12.066 \\
\hline
\end{tabular}

Table (9): Some physical and aerodynamic properties of corn (hyb.352)

\begin{tabular}{|c|c|c|c|c|c|c|c|}
\hline symbol & $\mathrm{L}$ & $\mathrm{W}$ & $\mathrm{T}$ & $\mathrm{V}$ & $D_{g}$ & $D_{a}$ & $A_{p}$ \\
\hline Max. & 14.985 & 10.949 & 6.880 & 434.704 & 9.400 & 9.908 & 109.640 \\
\hline Min. & 10.085 & 5.486 & 3.020 & 106.170 & 5.876 & 6.570 & 44.519 \\
\hline Sum. & 1845.063 & 1237.071 & 680.470 & 36225.485 & 1149.467 & 1254.201 & 11959.439 \\
\hline Mean & 12.300 & 8.247 & 4.536 & 241.503 & 7.663 & 8.361 & 79.730 \\
\hline Std.Dev. & 1.047 & 1.246 & 0.904 & 66.478 & 0.708 & 0.657 & 14.227 \\
\hline C.V. & 8.514 & 15.103 & 19.929 & 27.527 & 9.241 & 7.861 & 17.844 \\
\hline symbol & $\mathrm{M}$ & $\mathrm{S} \%$ & $A_{f}$ & $A_{t}$ & $v_{t}$ & $C_{d}$ & $N_{\mathrm{Re}}$ \\
\hline Max. & 0.540 & 79.560 & 109.696 & 50.910 & 16.300 & 0.623 & 11340.741 \\
\hline Min. & 0.180 & 46.207 & 44.542 & 14.031 & 13.500 & 0.139 & 6783.022 \\
\hline Sum. & 45.390 & 9379.371 & 11965.505 & 4406.109 & 2203.460 & 42.408 & 1393455.01 \\
\hline Mean & 0.303 & 62.529 & 79.770 & 29.374 & 14.690 & 0.283 & 9289.700 \\
\hline Std.Dev. & 0.056 & 5.838 & 14.234 & 7.326 & 0.725 & 0.088 & 968.678 \\
\hline C.V. & 18.471 & 9.337 & 17.844 & 24.941 & 4.933 & 31.118 & 10.427 \\
\hline
\end{tabular}


Table (10): Some physical and aerodynamic properties of Wheat (Giza 9).

\begin{tabular}{|c|c|c|c|c|c|c|c|}
\hline symbol & $\mathrm{L}$ & $\mathrm{W}$ & $\mathrm{T}$ & $\mathrm{V}$ & $D_{g}$ & $D_{a}$ & $A_{p}$ \\
\hline Max. & 7.580 & 5.970 & 3.910 & 74.698 & 5.226 & 5.433 & 30.365 \\
\hline Min. & 5.290 & 3.010 & 2.060 & 19.495 & 3.340 & 3.557 & 12.939 \\
\hline Sum. & 953.610 & 591.270 & 481.530 & 6400.404 & 644.988 & 675.470 & 2957.029 \\
\hline Mean & 6.357 & 3.942 & 3.210 & 42.669 & 4.300 & 4.503 & 19.714 \\
\hline Std .Dev & 0.410 & 0.630 & 0.449 & 11.606 & 0.399 & 0.363 & 3.600 \\
\hline C.V. & 6.455 & 15.977 & 14.000 & 27.201 & 9.276 & 8.055 & 18.264 \\
\hline symbol & $\mathrm{M}$ & $\mathrm{S} \%$ & $A_{f}$ & $A_{t}$ & $v_{t}$ & $C_{d}$ & $N_{\mathrm{Re}}$ \\
\hline Max. & 0.066 & 83.829 & 30.381 & 17.114 & 10.500 & 0.976 & 3649.353 \\
\hline Min. & 0.022 & 53.204 & 12.946 & 5.169 & 5.100 & 0.335 & 1330.663 \\
\hline Sum. & 7.048 & 10162.033 & 2958.529 & 1505.871 & 1201.200 & 88.459 & 377978.874 \\
\hline Mean & 0.047 & 67.747 & 19.724 & 10.039 & 8.008 & 0.590 & 2519.859 \\
\hline Std.Dev & 0.009 & 5.903 & 3.602 & 2.539 & 1.078 & 0.123 & 418.422 \\
\hline C.V. & 19.484 & 8.713 & 18.264 & 25.287 & 13.468 & 20.844 & 16.605 \\
\hline
\end{tabular}

Table (11): Some physical and aerodynamic properties of Wheat (Giza 168)

\begin{tabular}{|c|c|c|c|c|c|c|c|}
\hline symbol & $\mathrm{L}$ & $\mathrm{W}$ & $\mathrm{T}$ & $\mathrm{V}$ & $D_{g}$ & $D_{a}$ & $A_{p}$ \\
\hline Max. & 7.550 & 5.120 & 4.250 & 63.999 & 4.964 & 4.997 & 24.862 \\
\hline Min. & 5.060 & 3.010 & 2.010 & 20.942 & 3.420 & 3.683 & 12.416 \\
\hline Sum. & 938.710 & 543.870 & 480.500 & 5721.544 & 622.842 & 654.360 & 2671.372 \\
\hline Mean & 6.258 & 3.626 & 3.203 & 38.144 & 4.152 & 4.362 & 17.809 \\
\hline Std. Dev & 0.453 & 0.432 & 0.533 & 8.661 & 0.325 & 0.281 & 2.443 \\
\hline C.V. & 7.232 & 11.917 & 16.652 & 22.706 & 7.823 & 6.446 & 13.719 \\
\hline symbol & $\mathrm{M}$ & $\mathrm{S} \%$ & $A_{f}$ & $A_{t}$ & $v_{t}$ & $C_{d}$ & $N_{\mathrm{Re}}$ \\
\hline Max. & 0.066 & 88.321 & 24.875 & 17.090 & 9.900 & 1.098 & 3092.319 \\
\hline Min. & 0.020 & 49.321 & 12.422 & 5.020 & 4.700 & 0.432 & 1385.294 \\
\hline Sum. & 6.324 & 9993.87 & 2672.727 & 1374.434 & 1137.30 & 99.028 & 339898.182 \\
\hline Mean & 0.042 & 66.626 & 17.818 & 9.163 & 7.582 & 0.660 & 2265.988 \\
\hline Std. Dev & 0.007 & 6.415 & 2.445 & 2.054 & 1.209 & 0.150 & 365.617 \\
\hline C.V. & 17.286 & 9.629 & 13.719 & 22.420 & 15.948 & 22.783 & 16.135 \\
\hline
\end{tabular}

\section{CONCLUSION}

Some physical and engineering properties of some field crops are presented in this study and it can be concluded that:

1. Stainless steel or galvanized iron have the lowest values of coefficient of friction so, It is recommended to use the stainless steel or galvanized iron in manufacturing of seed hopper used in planting machines, silos and storage containers with sides inclination of $40^{\circ}$ to allow an easily sliding for the studied grains.

2. The bulk density, geometric diameter, arithmetic diameter, sphericity and the seed three axial dimensions, length (L), width (W) and thickness (T) were determined. The physical properties of seed play an important 
role to select the proper sorting, separating and cleaning equipment and the main dimensions are considered in selecting and designing the suitable size of the screen perforations.

3. Seed projected area, coefficient of drag and terminal velocity were estimated. The average terminal velocities of grains were 4.17, 7.32, 7.02, $20.16,15.34,14.69,8.00$ and $7.58 \mathrm{~m} / \mathrm{s}$ for fennel flower, rice (Giza101), rice (Giza 177), broad bean, corn (hyb. 310), corn (hyb. 352), wheat (Giza9) and wheat (Giza 168) respectively.

4. The results showed that Reynold's number of the terminals velocity of the studied grains exceeds the critical velocity of Reynold's number $\left(\mathrm{R}_{\mathrm{N}}=2100\right)$ in the range of turbulent flow except the fennel flower seeds.

\section{REFRENCESS}

El-Raie, A.E.S., N.A. Hendawy and A.Z. Taib 1996. Study of physical and engineering properties for some agricultural product, Misr J. of Agric. Eng., 13 (1): 211-226.

El-Sahrigi, A. F. 1997. Fundamental of food processing engineering. Acad. Library. Egypt.

Hexing, H. U. 1989. Effect of design parameters on cleaning performance in an oscillating screen-blower cleaning unit. M.Sc. Thesis, Faculty of the Graduate School, universisy of the Phillippins,Los Banos,Phillippins.

Klenin, N. I., I. F. Popov and V. A. Sukun 1985. Agricultural machines theory of operation, computation of controlling parameters and the conditions of operation. A merind publishing Co., PVT. Ltd., New Delhi, pp. 633.

Kochhar, A. and C. K. Hira 1997. Nutritional and cooking evaluation of green gram cultivars. J. of Food Science and Technology. 34 (4): 328-330.

Lgathinathane, K. G. and H. D. Hana 1998. The physical measurement of quality in Canned Peas. Commonwealth Sci. and Ind. Org. (Australia) Bul. 154.

Matouk, A. M., S. M. Radwan, M. M. El-Kholy, and T. R. Ewies2004 Determination of seeds density and porosity for some cereal crops. Misr J. of Agric. Eng., 21 (3): 623-641. 
Nimkar, P. M. and P. K. Chattopadhyay 2001. Some physical properties of green gram. J. Agric. Eng. Res., 80 (2): 183189.

Nonami, S. k. and S. O. Nelson 2002. Dimensional and density data for seeds of cereal seed and other crops. Trans.of the ASAE. 45 (1): $165-170$.

Sabbah, M. A., S. N. Soliman and M. O. Yehia 1994. Physical properties of Egyptian paddy rice related to steeping process. Misr J. of Agric. Eng., 11 (1): 248-260.

Sitkei ,G. 1987. Mechanics of Agricultural Materials. Developments in Agricultural Engineering 8. ELSEVIER, Amsterdam, Oxford,New York, Tokyo. 294-295.

\section{الملخص العزبي}

دراسة الخصائص الفيزيائية والهندية لحبوب بعض المحاصيل الحقلية يحيى عبد الحميد الفوال " محمد على توفيق*" أحمد محمد سعد الدين الثنال** تهدف هذه الدراسة إلى توفير قاعدة بيانات ومعلومات عن الخصائص الطبيعية و الهندسية لبذور

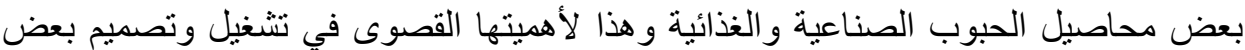

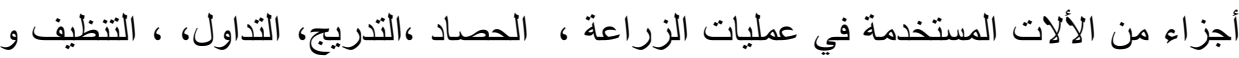

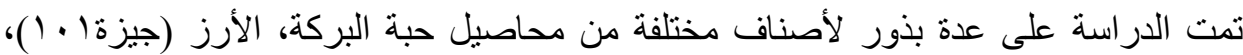

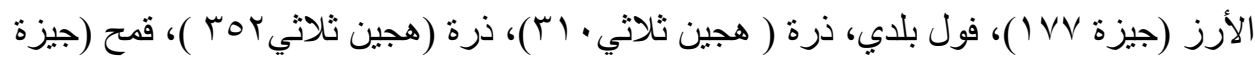

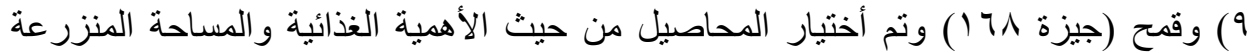

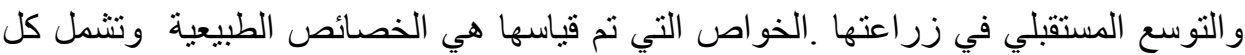

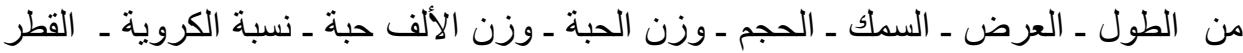

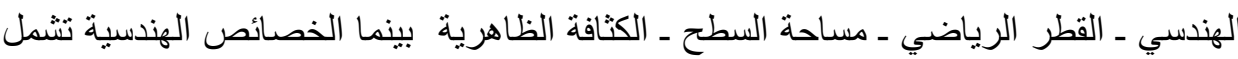
كل من الخصائص الميكانيكية ( معامل الأحتكاك ـ ز زاوية التكويم) و الخصائص التص الأيروديناميكية

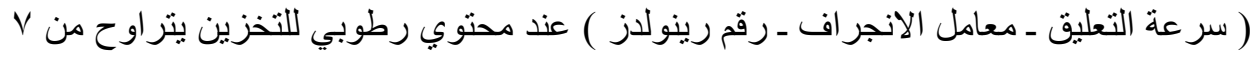

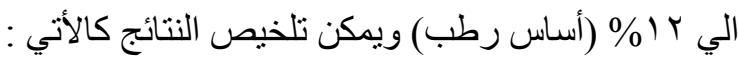

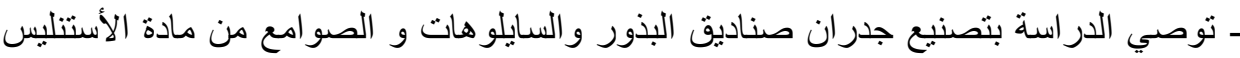

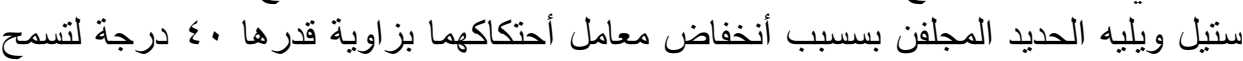
بانز لاق البذورتحت الدر اسة بسهولة. - حساب الخصائص الطبيعية تساعد علي أختبار الغرابيل وأقطار ثقوبها وكذللك أختبار ألات التدريج و الفصل المناسبة لبذور كل محصول. 


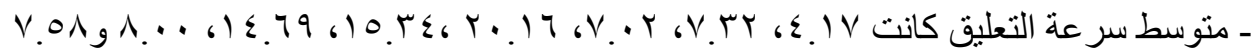

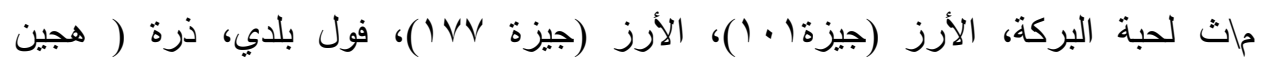

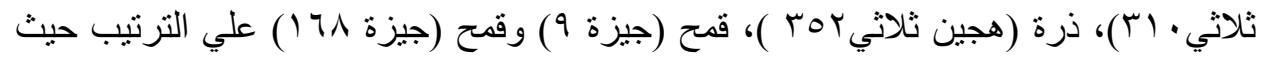

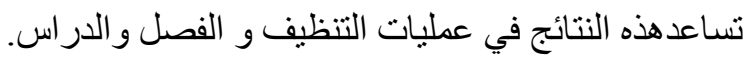

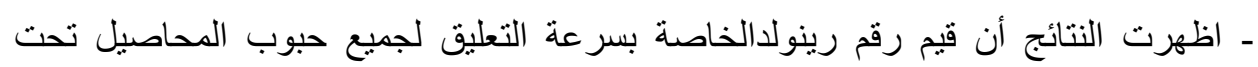

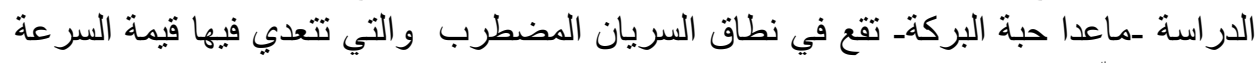

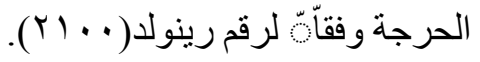

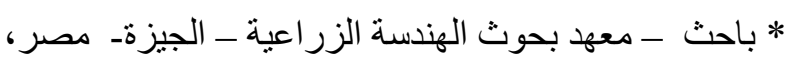

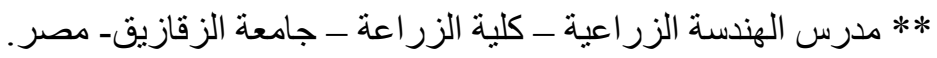

